\title{
Glacier-fed Himalayan rivers of India
}

\author{
R. K. Ganjoo \\ Department of Geology, University of Jammu, Jammu 180 006, India
}

in the rivers and subsequently, the water budget in rivers will fall substantially leading to the drying of rivers originating from the Himalaya ${ }^{1}$. There is another school of thought which believes that the rise in atmospheric temperature will not cause any serious impact on the glaciers in the Himalaya. There are several glaciers in the Himalaya (more particularly in Karakorum Himalaya) that are not affected by the rise in atmospheric temperature. Hence, these glaciers may not have any impact on the budget of the major rivers that originate from the Himalaya. In either case, water will be the major and significant issue that deserves attention from the perspective of climate change. Even though the water budget in Himalayan rivers may dwindle or remain unaffected due to climate change, the demand for water is likely to increase with a substantial increase in human population in the mountains in the near future. The propensity of water therefore will increase and so will conflicts related to distribution and usage of water among the states/countries.

Climate affects the hydrological cycle at both global and regional scales, and consequently the availability of, and demand for, water resources ${ }^{2-4}$. Climate change directly affects water resources through changing the quantity, variability, timing, form and intensity of precipitation, and indirectly impacts water resources through increasing water temperature, increasing evapotranspiration rate and decreasing water quality ${ }^{2,4-6}$.

The pessimistic view is that a warming climate will reduce available water and, particularly if combined with rising water demand, increase the propensity for waterrelated conflicts among the riparian countries, while the more optimistic view is that increasing temperature causes a depletion of snow and glacier storage in high-altitude regions that translates into an additional run-off, which at least in the next few decades will avoid a deterioration of the supply-demand ratio $^{7,8}$.

\section{Are the Himalaya glaciers melting?}

The melting of glaciers in the Himalaya is one issue that has no conclusive answer so far. The Intergovernmental Panel on Climate Change (IPCC) in its Assessment Report IV in 2007 had projected that glaciers in the Himalaya will vanish by AD 2035, which was not accepted by a large section of scientists/glaciologists in India. A document ${ }^{9}$ prepared by the Ministry of Environment and Forests, Government of India, recorded the erratic behaviour of glaciers across the Himalayas ${ }^{9}$. The scientific 
data suggest that the Himalayan glaciers are not responding to global warming/climate change in the strictest sense. The glaciologists who have been carrying out field mass balance study of glaciers in the Himalaya are of the view that some of the glaciers have the same or increased surface area, but are thinning ${ }^{10}$. In the Gravity Recovery and Climate Experiment (GRACE) satellite mission, it has been found that the glaciers in high-altitude Asia are losing ice one-tenth as fast as the previous estimates, and glaciers in the Tibetan Plateau are growing on average ${ }^{10}$.

The studies of 112 glaciers in Pakistan, Nepal and India suggested fluctuations between AD 1810 and 1970 (refs 11, 12). They further suggested that the glaciers located in the trans-Himalaya have been in the mode of advance since AD 1850 compared to those located in the other parts of the Himalaya, and that the fluctuation in glaciers shows no relation to the variation in monsoon except for the period between AD 1900 and 1909 that coincided with the peak in monsoon ${ }^{13}$. However, remote sensing studies suggest that glaciers in many parts of the Himalaya are advancing and also growing thick. This positive change in the Himalayan glaciers is ascribed to the enhanced monsoon precipitation associated with global warming ${ }^{13}$.

The scientific study of glacier fluctuations in the Himalaya for the last 100 years significantly emphasizes the difficulty in establishing any relationship between the climate factors and glacier fluctuation ${ }^{13}$. The improving health conditions of glaciers during the early Holocene $(\sim 11,000$ yrs BP) due to the insolation maxima provide a perfect analogy to the present-day changes in glaciers of the Himalaya ${ }^{13}$. The large extent of advance, in some of the Himalayan glaciers, during the early Holocene is a consequence of the increased insolation and intensified monsoon activity ${ }^{14}$.

The glaciers in some other parts of the Himalaya have not shown a large extent of advance during the same period. This is obviously because the maritime type of Himalayan glaciers respond to the fluctuation in monsoon, whereas the sub-polar type of glaciers are situated in arid regions of the Himalaya and are not affected by fluctuations in monsoon ${ }^{13}$. A study of the cause of termini fluctuation of 286 glaciers located between Hindukush and Bhutan Himalaya with lengths varying from 2 to $70 \mathrm{~km}$, revealed astonishing facts ${ }^{15}$. It is inferred that $65 \%$ of maritime type of glaciers are in the process of retreat, whereas $50 \%$ of sub-polar type of glaciers are either advancing or stable. The glaciers in Karakorum Himalaya show least impact of climate change on them due to the following:

(a) More moisture is transported to this part of the Himalaya due to the strengthening and shifting of Westerlies to lower elevations ${ }^{16}$.

(b) The winter precipitation has increased in the 20th century ${ }^{17}$. (c) There is a marginal decrease in summer temperature in the second half of the last century ${ }^{18}$.

A study on the impact of climate change on precipitation $^{19}$ reveals that PDD/SDD (prolonged dry days/short dry days) have significant increasing/decreasing trends for all ranges and altitudes in the Western Himalayan region. This indicates that the rainy days have decreased and the duration of dry spell has increased over the Western Himalayan region. The PDD do not show a clear trend for all ranges and altitudes, whereas SDD indicate an alternately decreasing and increasing trend in all ranges and altitudes. The study further reveals that no significant correlation has been observed for precipitation events in terms of intensity with El-Niño, while SDD show a significant positive correlation with El-Niño for the Great Himalaya and middle altitude. Except for the Great Himalaya, NAO (North Atlantic Oscillation) shows a positive correlation with low precipitation events for all ranges and altitudes.

The debris-covered glaciers in the Himalaya, almost $20 \%$, are interesting to study as far as the meltwater discharge due to climate change is concerned, as the rate of melt in glaciers with debris thickness exceeding a few centimetres reduces the rate of melting considerably despite the change in the climate ${ }^{20,21}$. Nevertheless, glaciers in the Indian Himalaya ${ }^{9}$, and Qilian and Tian Shan in China $^{22}$ have retreated since the middle of the 19th century by about $5-10 \%$. With about $16 \%$ of stable glacier fronts in the Hindukush, 28\% in southern Central Himalaya, $10 \%$ in northern Central Himalaya and very low $(1.5 \%)$ in the Western Himalaya, it is proposed that the Himalayan glaciers are not necessarily responding to climate change and instead are responsive to the topography and local climatic oscillations ${ }^{15}$.

\section{Will the Himalaya rivers continue to flow?}

The decrease in Hunza river run-off in the Indus Basin has been attributed to the cooling trend of the regional temperature, in general, and reduction in summer temperature and strengthening of winter precipitation, in particular $^{18}$. As a consequence, there is a reduction in ablation and an increase in the accumulation with a consequential effect on the decrease in river run-off. On the other hand, a study of river run-off in the Upper Indus basin presents a complex scenario with no significant change in the flow of the main Indus and Jhelum rivers between 1922 and 2004. The flow in the Chenab increased, whereas that in the Kabul river decreased during the same period ${ }^{23}$.

The contribution of snow and glacier water to the Ganges (10\%), Yangtze (8\%) and Yellow (8\%) rivers is limited owing to comparatively large downstream areas, limited upstream precipitation, smaller glaciers and/or wet monsoon-dominated downstream climate. In the Indus and Ganges basins, about $40 \%$ of the meltwater 


\section{REVIEW ARTICLES}

originates from glaciers, whereas in the other basins the glacial melt contribution is much less due to the low contribution of snow and ice as a consequence of limited upstream precipitation, smaller glaciers, wet monsoon and dominated downstream climates ${ }^{24}$. The normalized melt index (NMI) study to quantify the importance of both glacier and snow meltwater for five major river basins in Asia (the Indus, Ganges, Brahmaputra, Yangtze and Yellow) revealed very large differences among the basins, ranging from $46 \%$ snow and $32 \%$ glacier contributions in the Indus to $6 \%$ snow and $3 \%$ glacier contributions in the Ganges, which is largely dependent on the summer monsoon $^{25}$. Results from Variable Infiltration Capacity (VIC) model to assess the Yellow, Yangtze, Mekong, Salween, Brahmaputra and Indus rivers showed that all except Indus river were primarily dependent on rainfall run-off ${ }^{26}$.

Decrease in snow accumulation of Qomolangma (Mt Everest) from $\mathrm{AD} 1534$ to 1889 is due to reduction in northward incursion of summer South Asian monsoon as a consequence of change in dynamics of the summer South Asian monsoon ${ }^{27}$. The trend in the rate of accumulation of snow at Dasuopu (125 km from Qomolangma) is opposite for the same period ${ }^{28}$. This confirms that the variation in snow accumulation in the higher Himalaya is a factor of seasonal variation in monsoon systems versus westerly moisture systems that give rise to complex mountain meteorology ${ }^{27}$. Summer South Indian monsoon, the major contributor of precipitation to Himalaya, holds a key factor to the glacier hydrological system that still has not been well understood ${ }^{29,30}$. Studies suggest that $5000 \mathrm{~m}$ amsl, $90 \%$ of precipitation is in the form of snow, and in the lower parts of the Himalaya, snow contributes no more than $10 \%$ of the total rainfall ${ }^{29}$. The upstream water supply from Upper Indus, Ganges and Brahmaputra rivers is likely to decrease by $-8.4 \%,-17.6 \%$ and $-19.6 \%$ respectively, and at the same time there is a likelihood of an increase in mean upstream rainfall in Indus $(+25 \%)$, Ganges $(+8 \%)$ and Brahmaputra (+25\%), implying that the rivers originating from the Himalaya may not show any substantial decrease in their run-off ${ }^{24}$.

\section{Discussion and conclusion}

The recent controversy about overestimated melting rates of the Himalayan glaciers suggests, however, that our knowledge of high-altitude snow/ice and its response to climate forcing is still incomplete ${ }^{31-34}$. A 2010 study using measurements taken by the GRACE satellite mission indicated that the Third Pole is shedding roughly $50 \mathrm{Gt}$ of ice per year. An unpublished inventory of Tibetan glaciers led by Liu Shiyin at the Cold and Arid Regions Environmental and Engineering Research Institute in Lanzhou, China, shows that more than $70 \%$ of the glacier in the Tibetan Plateau are retreating. However, an analysis of GRACE data suggests that overall, high-altitude Asian glaciers are losing ice only one-tenth as fast as the previ- ous estimates and that those in the Tibetan Plateau are growing on average. The 46,000 or so glaciers in the Hindukush Himalaya region, also known as the Third Pole, supply water to southern and Central Asia, and although many climate studies suggest that the ice is disappearing fast, not all measurements are in support.

The scarcity of water in the world is not attributed to change in climate alone, but also to a manifold increase in the population, particularly in developing countries ${ }^{35}$. The severity of water shortage will largely be due to socio-economic developments and only $20 \%$ will depend on climate change ${ }^{36}$. The change in intensity, timing will affect the scarcity of water ${ }^{37,38}$. It is therefore a point of debate whether the change in the glacial hydrology is a factor of natural or anthropogenic climate change or overpopulation in mountain ecosystems that are seriously telling upon the increasing demand and not decreasing supply $^{39,40}$. The variation in climate between mountain valleys and mountain tops, between aspects and orientations, and different locations further complicates the mountain ecosystems ${ }^{30}$. The large uncertainty associated with the future precipitation projections as shown with the comparison of different general circulation models ${ }^{41}$ further compounds the issue of understanding glacier hydrology in mountain systems. Environmental researchers now see the supposed Himalayan crisis as partly due to political and social factors ${ }^{42-45}$ rather than the result of proven and tested physical processes.

1. Gwyn, R. H. and Collins, D. N., An assessment of the potential impacts of climatic warming on glacier-fed river flow in the Himalaya, climate variability and change - hydrological impacts. In Proceedings of the Fifth FRIEND World Conference, Havana, Cuba, IAHS Publications, 2006, vol. 308, pp. 473-477.

2. Arnell, N. W., A single water balance model for the simulation of stream flow over a large geographic domain. J. Hydrol., 1999, 217(3-4), 314-335.

3. Parry, M., Canziani, O., Palutikof, J., van der Linden, P. and Hanson, C., Climate Change 2007: Impacts, Adaptation and Vulnerability. In Contribution of Working Group II to the Fourth Assessment Report of the Intergovernmental Panel on Climate Change, Cambridge University Press, 2007.

4. Rosenzweig, C., Strzepek, K. M., Major, D. C., Iglesias, A., Yates, D. N., McCluskey, A. and Hillel, D., Water resources for agriculture in a changing climate: International case studies. Glob. Environ. Change, 2004, 14, 345-360.

5. Bates, B. C., Kundzewicz, Z. W., Wu, S. and Palutikof, J. P., Climate Change and Water, Technical Paper of the Intergovernmental Panel on Climate Change, Geneva, Switzerland, 2008.

6. Kundzewicz, Z. W. et al., Freshwater resources and their management. In Climate Change 2007: Impacts, Adaptation and Vulnerability. Contribution of Working Group II to Fourth Assessment Report of IPCC (ed. Parry, M. L.), 2007, pp. 173-210.

7. Malone, E. L., Changing glaciers and hydrology in Asiaaddressing vulnerabilities to glacier melt impacts, Tech. Rep., USAID, 2010.

8. Siegfried, T. et al., Will climate change exacerbate water stress in Central Asia? Climatic Change, 2012, 112, 881-899.

9. Raina, V. K., Himalayan Glaciers: A State-of-Art Review of Glacial Studies, Glacial Retreat and Climate Change, Ministry of 
Environment and Forest Discussion Paper, New Delhi, India, 2009 .

10. Qiu, J., Glaciologists to target the third pole. Nature, 2012, 484(7392), 19.

11. Mayewski, P. A. and Jeschke, P. A., Himalayan and TransHimalayan glacier fluctuations since AD 1812. Arctic Alpine Res., 1979, 11(3), 267-287.

12. Mayewski, P. A., Pregent, G. P., Jeschke, P. A. and Ahmad, N., Himalayan and Trans-Himalayan glacier fluctuations and the South Asian Monsoon record. Arctic Alpine Res., 1980, 12, 171182.

13. Owen, L. A., Latest Pleistocene and Holocene glacier fluctuations in the Himalaya and Tibet. Quat. Sci. Rev., 2009, 28, 2150 2164 .

14. Benn, D. I. and Owen, L. A., The role of the Indian summer monsoon and the midlatitude westerlies in Himalayan glaciation; review and speculative discussion. J. Geol. Soc. London, 1998, 155, 353-364.

15. Scherler, D., Bookhagen, B. and Strecker, M. R., Spatially variable response of Himalayan glaciers to climate change affected by debris cover. Nature Geosci., 2011, 4, 156-159.

16. Archer, C. L. and Caldeira, K., Historical trends in the jet streams Geophys. Res. Lett., 2008, 35, L08803; https://doi:10.1029/ 2008GL033614.

17. Treydte, K. S., Schleser, G. H., Helle, G., Frank, D. C., Winiger, M., Hang, G. H. and Esper, J., The twentieth century was the wettest period in northern Pakistan over the past millennium. Nature, 2006, 440(7088), 1179-1182.

18. Fowler, H. J. and Archer, D. R., Conflicting signals of climatic change in the upper Indus basin. J. Clim., 2006, 19, 4276-4293.

19. Shekhar, M. S., Devi, U., Paul, S., Singh, G. P. and Singh, A., Analysis of trends in extreme precipitation events over Western Himalaya Region: intensity and duration wise study. J. Ind. Geophys. Union, 2017, 21(3), 223-229.

20. Mattson, L. E., Gardner, J. S. and Young, G. J., Ablation on debris covered glaciers: an example from the Rakhiot Glacier, Punjab, Himalaya in snow and glacier hydrology. In Proceedings of an International Symposium held at Kathmandu, Nepal, 16-21 November 1992 (ed. Young, G. J.), IAHS Publication, 1993, vol. 218, pp. 289-296.

21. Østrem, G., Ice melting under a thin layer of moraine, and the existence of ice cores in moraine ridges. Geogr. Ann., 1959, 41, 228-230.

22. Li, X. et al., Cryospheric change in China. Global Planet. Change, 2008, 62(3-4), 210-218.

23. Ali, G., Hasson, S. and Khan, A., Climate Change: Implications and Adaption of Water Resources in Pakistan, Research Report RR 13. Global Change Impact Studies Centre, Islamabad, Pakis$\tan , 2009$.

24. Immerzeel, W. W., van Beek, P. H., Ludovicus and Bierkens, M. F. P., Climate change will affect the Asian Water Towers. Science, 2010, 328(5984), 1382-1385.

25. Immerzeel, W. W., Pellicciotti, F. and Bierkens, M. F. P., Rising river flows throughout the twenty-first century in two Himalayan glacierized watersheds. Nature Geosci., 2013, 6, 742-745.

26. Zhang, L., Su, F. and Yang, D., Discharge regime and simulation for the upstream of major rivers over Tibetan Plateau. J. Geophys. Res.: Atmos., 2013, 118(15), 8500-8518.

27. Kaspari, S., Hooke, R. L., Mayewski, P. A., Kang, S., Hou, S. and Qins, D., Snow accumulation rate on Qomolangma (Mount Ever- est), Himalaya: synchroneity with sites across the Tibetan Plateau on 50-100 year timescales. J. Glaciol., 2008, 54(185), 343-352.

28. Davis, M. E., Thompson, L. G., Yao, T. and Wang, N., Forcing of the Asian monsoon on the Tibetan Plateau: evidence from high resolution ice core and tropical coral records. J. Geophys. Res., 2005, 110(D4), D04101; 10.1029/2004JD004933.

29. Winiger, M., Gumpert, M. and Yamout, H., KarakorumHindukush-Western Himalaya: Assessing high-altitude water resources. Hydrol. Proc., 2005, 19, 2329-2338.

30. Hewitt, K., Glacier change, concentration, and elevation effects in the Karakoram Himalaya, Upper Indus Basin. Mt. Res. Dev., 2011, 31(3), 188-200.

31. Bagla, P., No sign yet of Himalayan meltdown, Indian report finds. Science, 2009, 326(5955), 924.

32. Bagla, P., Climate science leader Rajendra Pachauri confronts the critics. Science, 2010, 327(5965), 510.

33. Cogley, J. G., Kargel, J. S., Kaser, G. and van der Veen, C. J., Tracking the source of glacier misinformation. Science, 2010, 327(5965), 522.

34. Canziani, M. O., Palutikof, J., van der Linden, P. and Hanson, C. B., Climate Change 2007: Mitigation of Climate Change. In Contribution of Working Group III to the Fourth Assessment Report of the Intergovernmental Panel on Climate Change, Cambridge University Press, Cambridge, 2007.

35. Vorosmarty, C. J., Green, P., Salisbury, J. and Lammers, R. B., Global water resources: vulnerability from climate change and population growth. Science, 2000, 289(5477), 284-288.

36. Ehrhart, C., Thow, A. and Warhurst, A., Humanitarian Implications of Climate Change: Mapping Emerging Trends and Risk Hot Spots, CARE International, 2008, p. 36.

37. World Water Assessment Programme, World Water Development Report: Water for People, Water for Life, 2003; http://www. unesdoc.unesco.org/images/0014/001431/143120E.pdf

38. UNESCO, From Potential Conflict to Cooperation Potential: Water for Peace-Prevention and Resolution of Water Related Conflicts, 2006; http://www.unesco.org

39. Rogers, P., The Global Water Crisis: Six Steps for Survival. In Athens International Symposium on Water Sustainable Development and Water: A Global Challenge For Local Actions, 22-23 October 2009.

40. Sadik, N., Population information, education and communication. Asia-Pacific POPIN Bull., 1995, 7(3), 6-10.

41. Saeed, F., Anis, M. R., Aslam, R. and Khan, A. M., Development of Climate Change Scenarios for Specific Sites Corresponding to Selected GCM Outputs, Using Statistical Downscaling Techniques, Research Report RR 09. Global Change Impact Studies Centre, Islamabad, Pakistan, 2009.

42. Forsyth, T., Science, myth and knowledge: testing Himalayan environmental degradation in Thailand. Geoforum, 1996, 27(3), 375-392.

43. Ganjoo, R. K., Glaciers and global warming. Eternal India, 2008, 1(3), 139-149.

44. Ganjoo, R. K., Is anthropogenic global warming real? Eternal India, 2010, 2(4), 139-147.

45. Ganjoo, R. K., A Himalayan goof-up or corporate malfides? Eternal India, 2010, 2(6), 64-71.

Received 23 January 2021; revised accepted 21 April 2021

doi: $10.18520 / \mathrm{cs} / \mathrm{v} 121 / \mathrm{i} 2 / 210-213$ 